How to cite:

Mateus, Samuel (2015) "Public and Multitude- the (un)expected relation" In Torres e Mateus (ed.), From Multitude to Crowds: collective action and the Media, Frankfurt am Main, Peter Lang, 2015, p.71-86.

\title{
Publics and Multitudes- the (un)expected relation
}

\author{
Samuel Mateus \\ Madeira University \\ samuelmateus@uma.pt
}

\begin{abstract}
:
The public sphere theory and multitude theory are traditionally seen as being apart. The public and the multitude seem so distant notions that we never look into them with a comparative viewpoint. In some respects, the multitude seem to be the opposite of the public, many times inappropriately compared with crowds or mobs. So, the relation between the public and the multitude seem to be a bit unexpected.

In this paper, we theoretically exam these notions putting them in perspective looking for the expected (hopeful) relation. The analysis departs from five features - inclusiveness, the common, social body, plural singularities and revolutionary subject. In each one we search where the public and the multitude meet and where they differ. In this frame of analysis we will suggest that, at some angles, the multitude is a kind of pre-public: an immanent power that eventually evolves to a potential critical reasoning force.
\end{abstract}

Key-Words: Multitude; Public; Crowd; Public Sphere; Sociology of Communication; Hardt and Negri;

\section{Introduction}

The occupation of public space. The collective coordination made by singular individuals. Or the expansive networks of commitment toward a mutual goal. What does all these actions have in common? All the three entail a working compromise with the concepts of crowd, public and multitude. They also show how difficult it is today to fully separate the constitutive continuity between these major notions of social and political theory.

Contemporary times, with the prominence of social movements (such as the Occupy Wall Street Movement, in USA) and spontaneous manifestations (Je suis Charlie, in France) confirm the growing importance of civic crowds, political publics and the potential of the multitude. Yet, we live in a time where crowds have been excluded from the central domain of sociological analysis (Borch, 2013: 2), publics have entered a steady decline (Lippman, 1925; Habermas, 1962; Sennett, 1974) and the multitude is not an idea without serious problems (Marcos, 2009: 28). How can one conciliate the seemingly contradiction where we watch, in internet age, the rise of smart mobs (Millan, 2013) or virtual crowds (Mazzarella, 2010: 697), and at the same time the denigration or depreciation of crowds? Mazzarella points us to a possible explanation why we tend to speak of multitudes rather than crowds. "Crowds are the dark matter that pull on the 
liberal subject from its past, whereas multitudes occupy the emergent horizon of a postliberal politics" (Mazzarella 2010: 697).

Mobs and crowds flourished in the $18^{\text {th }}$ and $19^{\text {th }}$ century psychological and sociological literature expressing the paradox of being both a potential to mass democratization and a risk to urban order. They were believed to threat power from the outside (Cannetti, 1960) although were initially described as dumb and uncivilized: "In crowds it is stupidity and not mother-wit that is accumulated" (Le Bon, 1895: 6). Crowds are "like a savage not prepared to admit that anything can come between its desire and the realization of its desire" (Le Bon, 1895: 22).

In the late $19^{\text {th }}$ century a culture consuming public consolidated the advertising-supported mass media. Authors like Lippman (1922) regretted the displacement of a reasoned public opinion by a public dominated by the sheer power of numbers. Le Bon, once again, help us understand this dislodgment when emphasizes the way "“popes, kings and emperors consent to be interviewed as a means of submitting their views on a given subject to the judgment of crowds" (Le Bon, 1895: 96).

At the same time, crowds seen an amorphous collective menacing the moral order was linked to masses, the anonymous and homogeneous aggregate that came with large-scale industrialization and urban life. But while crowds and mobs can be characterized as temporary assemblies gathering at specific time and places, masses were more of a conceptual term (Bratich, 2005: 249). Since it referred a way of metaphorically denote the loosening of the individual in huge collectivities it is an abstract category of social thinking. In addition, unlike crowds, masses were undifferentiated, passive and thought to be easy manipulated by massmedia. "The essence of the masses is indifference: all differences are submerged and drowned in the masses. All the colors of the population fade to gray. These masses are able to move in unison only because they form an indistinct, uniform conglomerate" (Hardt and Negri, 2004: xiv).

Even if the multitude denotes a multiplicity or an expanded set of relations (Hardt and Negri, 2000: 103), it must not be confounded with crowds. Hardt and Negri make a clear distintion between the multitude and crowds. "Since the different individuals or groups that make up the crowd are incoherent and recognize no common shared elements, their collection of differences remains inert and can easily appear as one indifferent aggregate. The components of the masses, the mob, and the crowd are not singularities-and this is obvious from the fact that their differences so easily collapse into the indifference of the whole. Moreover, these social subjects are fundamentally passive in the sense that they cannot act by themselves but rather must be led. The crowd or the mob or the rabble can have social effects-often horribly destructive effects-but cannot act of their own accord. That is why they are so susceptible to external manipulation. The multitude, designates an active social subject, which acts on the basis of what the singularities share in common" (Hardt and Negri, 2004: 100). Since Maquiavelli, the idea of multitude has attracted much attention. From a political point of view, it may even be a better concept than the Hobbesian "people", as Virno (2004), following Spinoza, has argued.

Still, we need to deal with crowds todays. All it takes to realize it is to turn television on. Today's resurgence of revolutionary crowds draws our attention to joint forms of public contestation that resembles the idea of multitude as an immanent and collective social subject. Multitudes are close to crowds when they give rise to rallying events such as the globalization protests in Seattle, Genoa and Gotemburg. Hardt and Negri (2004) themselves give these examples of how the multitude had formed and exhibited its resistance. It is precisely this possibility of the multitude to entail collective action and social criticism that suggests a study on the relations between crowds, multitudes and publics could be pursued.

We agree with Mazarella (2010: 715) when he claims that the apparent negativity of crowds is actually a sign of their relevance. If we stop using the crowd in contrast to classical crowd psychology literature and embarking in a more nuanced reading of crowds, we can prevent its oversimplification. At the same time, we may restore the notion some of its due complexity and take up the challenge to ponder it in connection with the multitude. We also align with Borch 
(2013: 294) and agree that crowds had not become obsolete or that they should be discarded from sociological attention. Contrariwise, contemporary diagnoses benefit from establishing links between the crowd, the multitude and the public. It was also Le Bon who draw attention to the fact of crowds being more than the sum of its members. Crowds were described as a kind of organism; they have an identity. By looking into today's multitude's repertoires of action we see how hard it is to separate it from crowds. And when attesting those repertoires of action we also see how the idea of public must now not be far if we intend to comprehend it.

How can we, in contemporary societies, articulate both? Are there multitudes without publics? After the theory of the Public Sphere (Habermas, 1962), or Dayan's perspective on AlmostPublics (Dayan, 2001), for example, are Publics still relevant, or were they subsumed by multitudes?

This paper will ponder on the possible relations of the public and the multitude from a theoretical point of view. It will not posit a normative theory but it will try to sketch the benefits of looking on society from this comparative perspective. Ultimately, it will bring to light the affinities we encounter in them when we displace or put in perspective these social categories. It will argue there are some dimension from which a prolific dialogue can be established about the roles the multitude and the public may play today. We hope in the end that features like inclusiveness, the common, the existence of a social body, plural singularities and revolutionary subject, make clear how far these notion are today related.

\section{Coincidences and Contrasts on the Public and the Multitude Conceptualizations}

We will differentiate five dimensions present in both the public and the multitude, trying to define the borders where the notion meet and where they diverge. Is some cases, as we will see, the contrast is due, not to a radical nature of the conceptualization but due to different appreciations of the same feature.

\section{Inclusiveness}

In classical Greek political thought the multitude is known as hoi polloi, the many or majority, or even the common people on a derogatory sense. In History of the Peloponnesian War, Thucydides uses the term when referring to Pericles' Funeral Oration speech. But when Greeks wanted to mention the multitude they also used plethos. Similar to Greeks, ancient Romans used the term plebeius to denote plebs or laypeople. In English the word multitude derives from the latin multitudo, meaning a throng, horde or a mass congregation of ordinary people.

How Habermas defines the public in The Structural Transformation of the Public Sphere about the Bourgeois Public Sphere may be very revealing: "The bourgeois public sphere may be conceived above all as the sphere of private people come together as a public" (Habermas, 1962: 27). Let's emphasize this coming together. It seems there is a kind of informal unity in the public, even if it is composed by an elusive host of individuals coming from different parts and not necessarily having any relation between them except a common interest in some occurrence, event or problem. "The public, indeed (...) is a crowd dispersed, where the influence of spirits on each other became an action remotely, and increasingly at large distances" (Tarde, 1901: 7).

So, the first comparison we want to make concerns the physical dispersion of the Public and the multitude. Like the Public (and unlike the crowd), the multitude entails a physical dispersion, a scattered diffusion of its members, a distributed network of different individuals joining together. By another hand, like the public, it reaches its most prominence because it assembles a mass of detached individuals around an issue. Its force begins in the sheer amount of people 
it can put together and aligned. Both concepts point to an indefinite extension, a vast and unlimited collectivity ${ }^{1}$.

Thomas Hobbes, although giving the multitude an a-political character, designates the multitude as a significant social aggregate. "Because multitude is a collective word, it is understood to signify more than one object, so that a multitude of men is the same as many men. Because the word is grammatically singular, it also signifies on thing, namely a multitude" (Hobbes, 1642: 76). In a multitude there are always too many individuals to order it or find stable, hierarchical structures. This is a good thing since it encompasses, not an exclusive but an inclusive concept. Anyone can take part in the multitude. In Hobbes, this inclusive character is made the pivotal center to separate the multitude, a dispersed non-spatial gathering, and State (and People). This is not the occasion to deepen the political philosophy of Hobbes. Suffice is to say, that in Hobbes we have already an encompassing conception of the Multitude. It is this capacity to include anyone independently of their differences or distance that make it near from the idea of Public. This is also relevant form the public point of view. The normative theory of the public sphere puts this openness and inclusiveness at the forefront making it a condition to the operative function of the Public (Habermas, 1962: 27).

\section{The Common}

Let's recall once again what Habermas tells us in The Structural Transformation of the Public Sphere: "We call events and occasions "public» when they are open to all, in contrast to closed or exclusive affairs"(Habermas, 1962: 6). This is the sense of expressions such as public education, public health and public opinion. More importantly, he stresses the link between what is common and what is public. "The commons was public, publica; for common use there was public access to the fountain and market square-loci communes, loci publici" (Habermas, 1962: 6). So there is a connection between publicity and the common, open, collective access to something. To Arendt, the public sphere is exactly this "common world that gather us together and prevents our falling over each other" (Arendt, 1958: 52).

One of the key instances of the (bourgeois) public sphere was "a kind of social intercourse that, far from presupposing the equality of status, disregarded status altogether. The tendency replaced the celebration of rank with a tact befitting equals (...) the parity of "common humanity" ("bloss Menschliche"). Les hommes, private gentlemen, or die Privatleute made up the public not just in the sense that power and prestige of public office were held in suspense; economic dependencies also in principle had no influence. Laws of the market were suspended as were laws of the state. Not that this idea of the public was actually realized in earnest in the coffee houses, the salons, and the societies; but as an idea it had become institutionalized and thereby stated as an objective claim" (Habermas, 1962: 36). Discussion within such a public presupposed the problematization of areas that until then had not been probed. The struggle against a monopoly of interpretation putted individuals in the same common ground, a community of critical enquiry.

\footnotetext{
${ }^{1}$ In Christian tradition, multitude usually describes a mass of people disrupting of political order and justice (Jakonen, 2011: 5). Machiavelli's Discourses on the First Decade of Titus Livius, are a good example of this disorderly and destructive dimension of the multitude. "The multitude, following the lead of these powerful men, took up arms against the prince and, he being got rid of, obeyed these others as their liberators; who, on their part, holding in hatred the name of sole ruler, formed themselves into a government and at first, while the recollection of past tyranny was still fresh, observed the laws they themselves made, and postponing personal advantage to the common welfare, administered affairs both publicly and privately with the utmost diligence and zeal". More, the multitude has not a political character: "For though the multitude be unfit to set a State in order, since they cannot, by reason of the divisions which prevail among them, agree wherein the true well-being of the State lies, yet when they have once been taught the truth, they never will consent to abandon it" (Maquiavelli, 1517).
} 
When discussing the multitude Hardt and Negri talk on "the production of the common" (2004: 196). "What it produces, in fact, is common, and that common we share serves as the basis for future production, in a spiral, expansive relationship. This is perhaps most easily understood in terms of the example of communication as production: we can communicate only on the basis of languages, symbols, ideas, and relationships we share in common, and in turn the results of our communication are new common languages, symbols, ideas, and relationships. Today this dual relationship between production and the common-the common is produced and it is also productive-is key to understanding all social and economic activity" (Hardt and Negri, 2004: 197). What they seem to be saying is that social life depend on the common partaking of life.

If we take the public as a category of the common, we also need to consider publicity in the formation of the multitude. The multitude produces the common aspect of life but it is the public that manufactures a common life. The means to establish the social are influenced by the quality of public life and its ability to raise the common. The multitude, as described by Hardt and Negri, seem to build upon this pre-existing commonality. This is why the authors felt the urgency to refer to communication while stressing the production of the common in the multitude. Against the "expropriation of the common" (Hardt and Negri, 2004: 188) they identified in capitalism and private property, they appeal to the open, accessible and mutual grounds present in communication, be it as symbolic interaction, be it as digital technologies based on the immaterial and intellectual property. This common is what the Italian philosopher Paolo Virno, following Marx, calls the "general intellect" (Virno, 2004: 64).

The main objective to Hardt and Negri when bringing the multitude to discussion seems to lie in the weight they subtly put on communication to put the common in practice. "In the multitude, social differences remain different. The multitude is many-colored, like Joseph's magical coat. Thus the challenge posed by the concept of multitude is for a social multiplicity to manage to communicate and act in common while remaining internally different" (Hardt and Negri, 2004: xiv). If the multitude should reveal, not an identity (People) nor a uniformity (masses), those internal differences should discover the common that will enable her to communicate and act together.

Just like the public is based on a steady and consistent communicational work (Habermas, 1962), the multitude argued by Hardt and Negri seems to discreetly dependent on communication to work the common. "Our communication, collaboration, and cooperation are not only based on the common, but they in turn produce the common in an expanding spiral relationship" (Hardt and Negri, 2004: xv). Since it represents a decentralized network, the Internet is believed to be a first draft model to the multitude for two main reasons: "first, the various nodes remain different but are all connected in the Web, and, second, the external boundaries of the network are open such that new nodes and new relationships can always be added" (Hardt and Negri, 2004: xv).

At this point, we need to resist the temptation to equal the public and the multitude. In fact, a Res publica is not the same as a Res communis. "The common marks a new form of sovereignty, a democratic sovereignty (or, more precisely, a form of social organization that displaces sovereignty) in which the social singularities control through their own biopolitical activity those goods and services that allow for the reproduction of the multitude itself" (Hardt and Negri, 2004: 206).

But this common of the multitude does not have for consequence a constituted, institutional substance (like public opinion in the public) or a Gemeinshaft but mostly this common signifies a productive activity of singularities. Even though the public and the multitude deal with the common, they deal with it differently: in one case as a platform to collective discussion and critical subjectivity; in the other case, as an emergent substance of cooperation to a new kind of subjectivity.

\section{A Social Body in Power (potentia)}


This new type of subjectivity, as claimed by Hardt and Negri (2004), can be better approached through the political philosophy of Spinoza. For Spinoza, unlike Hobbes, there is no mediation of a contract required to socialize individuals, nor there is a total transfer of natural rights (Armstrong, 2009: 279). In fact, there is a strict coincidence of right and power. That I have the right to act means that I have the desire to act and that I have no internal or external impediments to do so. Spinoza then concludes that natural right is primary power (potentia), therefore, inalienable to a political power (potestas). "When Spinoza speaks of a transfer of right, then, this cannot be understood in a juridical sense for it does not imply that transcendent transfer which results in an irreversible obligation on the part of the transferee. It is, rather, a process by means of which a new (and only relatively irreversible or stable) relation of forces is established" (Armstrong, 2009: 283).

The idea of contract appears in the Political Treatise to refer to the transfer of the multitude's right to one council or one man (Spinoza, 1677: 698). But if there is a right of the multitude it transfers, there must be a power of the multitude. The multitude is now regarded as social body or a unified collective entity. It is not a mere aggregation of individual powers (we would say a mob). "Natural right is now, for the first time, thought explicitly as the power of the mass (potentia multitudinis), hence as the 'right of number' (since jus=potentia), not, of course, in the sense of an arithmetic sum but in the sense of a combination, or rather, an interaction of forces" (Balibar, 1985: 15). So, to Spinoza, politics is not reduced to individual and the State. Rather, he considers those notions simple abstractions that are adequately apprehended when related to the multitude (Armstrong, 2009: 284). The civil state derives its power (potestas) from the multitude itself. Spinoza writes about political domination that is imposed by the multitude itself and not that one imposed from outside (Desmarest, 2011: 69).

The multitude gains in Spinoza a social form and political existence that is a power (potentia) in itself and the keystone of civil liberties. The multitude indicates, therefore, a plurality or a form of being many. In other words, the tradition associated with Spinoza, sees in the multitude the mode of being of the many (Virno, 2004: 22).

It is here we can trace some similarities with the idea of the public. As the multitude, the public is composed by a substrata of plural individuals. The public plural not just in its constitution but in its many forms (literary publics, political publics, aesthetic publics, television publics, etc). And like the multitude the public is believed to be a fundamental social body. More, it is a social and political body capable of articulating dissent and critically engage with the state. In this sense, the public is also a motor force of social transformation; it is a power. It is the amount of private individuals gathered in public together aiming to produce a Public Opinion. The public, like the multitude, is something more than the sum of its parts. It is a permanent and interstitial form of a free society. A power in itself.

The most significant aspect relating the public with the multitude is the latter's need of publicity. According to Virno the multitudes indicates "a plurality which persists as such in the public scene, in collective action, in the handling of communal affairs without converging into a One" (Virno, 2004: 21). Here it is an explicit correlation between the multitude and publicity, the multitude and the need to perform publicly (ex: Je suis Charlie is everywhere).

Just like the category of the public has moved the monopoly of free-thinking from the State to individuals, so the multitude is moving the monopoly of political decision-making away from the State. In both public and multitude, what is at stake is the will to put into practice a performativity and a power based, not in a synthetic unity but in a composite, mixed and crossbreed plurality. It is this plurality, this disseminated and distributed power that we see in both notions of the public and the multitude. They are both forms of collective agency.

\section{Plural Singularities}

So, the public and the multitude potentiate collectivities. The kind of collectivity is, nonetheless, quite dissimilar. The public, by one hand, is a much more political normative collectivity. It is a 
kind of a critical subject always discussing and debating in order to produce an enlightened Public Opinion. It is a collective driven by the opposition or conflict to the State. It is located in a public sphere in-between the sphere of Public authority and the private realm (Habermas, 1962: 30). Individuals are taken to be mostly readers, spectators and auditoires.

In the case of the multitude, we have "plural singularities" (Hardt and Negri, 2004: 99) and "common singularities" (idem: 159). "The multitude is composed of a set of singularities-and by singularity here we mean a social subject whose difference cannot be reduced to sameness, a difference that remains different. The component parts of the people are indifferent in their unity; they become an identity by negating or setting aside their differences. The plural singularities of the multitude thus stand in contrast to the undifferentiated unity of the people" (Hardt and Negri, 2004: 99).

Resuming the idea of social body, the multitude could, thus be seen as a creative force of the many $^{2}$. A kind of strength given by its many constituents. It is this notion of the many that Aristotle has in mind when he contends superiority of the many in contrast to the few. "The principle that the multitude ought to be supreme rather than the few best is one that is maintained, and, though not free from difficulty, yet seems to contain an element of truth. For the many, of whom each individual is but an ordinary person, when they meet together may very likely be better than the few good, if regarded not individually but collectively, just as a feast to which many contribute is better than a dinner provided out of a single purse. For each individual among the many has a share of virtue and prudence, and when they meet together, they become in a manner one man, who has many feet, and hands, and senses; that is a figure of their mind and disposition. Hence the many are better judges than a single man of music and poetry; for some understand one part, and some another, and among them they understand the whole" (Aristotle, 1999: 66).

The multitude, because is formed by the many, is considered to make better decisions by pooling together the experience and knowledge of its individual members ${ }^{3}$. It can attain a better informed judgment than any single member of the body, however excellent it could be (Waldron, 1995: 564). According to Waldron, Aristotle is "committing himself to the proposition that the many acting collectively may be a better judge than the few best not only of matters of fact, not only of social utility, but also and most importantly of matters of ethics, value, and the nature of the good life-issues which go beyond the mere accumulation of individual experience" (Waldron, 1995: 569). There is an academic plea whether Aristotle is saying the rule of the multitude rested in its superior knowledge (the doctrine of the wisdom of the multitude) (Waldron, 1995), or in the belief that the virtue (moral and intellectual capabilities) of multitudes can be aggregated (Cammack, 2013). This epistemic and ethic discussion about the extent of Aristotle's words will not be taken here.

We want rather emphasize the holistic rule of the multitude in knowledge and in virtue. In other words, the kind of collectivity the multitude potentiate is based on the amplification of individual acts. This notion of amplification is of most significance. Individuals are not aggregated in a multitude (or else they would form a mass or a crowd), but each one of their proficiencies are assimilated and enlarged. For example, Aristotle tells us: "For all when assembled together have sufficient discernment, and by mingling with the better class are of benefit to the state, just as impure food mixed with what is pure makes the whole more nourishing than the small amount

\footnotetext{
${ }^{2}$ In a small note in his Philosophy of Right, Hegel discusses the idea of the many: "The expression "The Many» (o. polloi) characterizes the empirical universality better than the word "All," which is in current use. Under this "all," children, women, etc., are manifestly not meant to be included. Manifestly, therefore, the definite term "all" should not be employed, when, it may be, some quite indefinite thing is being discussed (Hegel, 1821)

${ }^{3}$ This perspective is the same present on Surowiecki's The Wisdom of Crowds (2004) although he refers to crowds. The main idea is that the aggregation of expertise forms a collective intelligence that could not be attained by individual capabilities alone.
} 
of pure food alone; but separately the individual is immature in judgment". This is of critical prominence since it helps us to separate the multitude and the public. The many persevere as many without aspiring to the unity (Virno, 2004: 80): its individual singularities do not aspire to universality because their generality is already in them. By other hand, the publics usually puts its collective action on the hands of individuated persons (private individuals assembling together in public). Individualization (not individuation) puts them on track with a universal (kantian) principle of criticism and use of reason (cf. Habermas, 1962: 102).

Let's now see the implications of this amplification in contrast to the notion of the public. Following Cammack's interpretation on the virtue of the multitude in Aristotle, it is easy to see how the multitude is a collectivity of a different kind than the public. According to the theory of the public sphere, the public is a rational-critical entity, discussing relevant issues to society. Its medium is speech and a privileged locus of debate is the political assembly. When discussing the multitude, Aristotle was most likely not thinking on debates in an assembly at all. He cites three specific examples of political activity that disregard assembly debates on mass political activity: election to important offices, audits, and judging cases in court. The verb bouleuomai suggests group discussion and can be equally applied in these cases. (Cammack, 2013: 180). In regard the speech, Aristotle could not have braced the political authority of the multitude on the basis of speech (logos) since his comments would also apply to animals which do not have an articulate reason. "The possession of logos, "articulate reason" or "speech," was to Aristotle the crucial difference between humans and divine beings on the one hand, and all other living creatures on the other. Under no circumstances could he have supposed that his argument would also apply to animals if speech played any part in it. It follows that speech cannot be a key feature of the political situations that he has in mind" (Cammack, 2013: 181).

So, two attributes of the public are not present in the multitude if we are to agree with Aristotle's perspective. Political assemblies and speech are not determinant in the multitude. He is more interested in the politeia, not in demokratia. This, once again, brings us crucial insights.

The multitude may be apprehended a collectivity based in plural singularities that should not be thought as dependent on logos or speech like the public. Instead, they involve a common emotion (like today's common fear of terrorism, or a common hope in peace in Israel). Passions have since Spinoza a directly socializing function and are cited by him as the principal cause of the constitution of the multitude. "Since men, as we have said, are led more by passion than by reason, it naturally follows that a people will unite and consent to be guided as if by one as ... a common hope, or common fear, or desire to avenge some common injury (Spinoza, 1677: 700). The point to note is that the type of sociability moving the multitude has its source on feelings. What binds them, after Spinoza, is the universal existence a common passion playing a unifying role in the network of individuals defining the multitude (ex: Manifestations of dissent and homage after the Charlie Hebdo killings in January 2015).

So, the multitude, more than a collective reasoning, encompasses a generalized feeling, a sharable sentiment. The multitude perpetrates a contagion. But unlike the primary contagion of the crowd (Tarde would call it the imitation), the multitude suggests a reciprocal influence or sympaty (syn-pathos). It is not a duplication rather than a unified affect. One could also say the multitude encompasses mirroring. So, it is not a surprise that the multitude sometimes evolve to crowds. The passional multitude can act and perform in many other ways (just like the Seattle anti-globalization protests demonstrate) including effervescence, aesthetic actions, and the occupation of the public space.

The multitude is close to the bare flesh, to ordinary individuals, to their own afflictions. It is a collectivity nourished by the social, by the encompassing notion of politeia, a community of citizens interest not just in politics but in their own civic community. The verb "politeuomai" means an active citizen of the city state. We will see we can refer to the multitude as a revolutionary subject.

\section{A Revolutionary Subject}


What is the most distinguishing feature between the public and the multitude? Where is the contrast between these old categories? A start of an answer would be in the downfall of the individual. Where the public is based on a strict subjectivity, the multitude is accused by the postliberal point of view of depreciate individuality. This points to different valorizations of the collective agency. Stating the plural singularities of the multitude means, especially after Hardt and Negri $(2000 ; 2004)$, it always comes first, it is an ontological foundation of society. It is fundamentally differentiated but nonetheless a collective subject and an explosion of multiply as a subject. Thus, for the authors of Empire and Multitude, democracy should be invented by the multitude. Its immanence signifies a political self-management and autonomy. Political and social innovation comes through the networks that digital technologies attest.

Both multitude and public entail a vital force or groundbreaking subject. Even so, in Hardt and Negri's vision, the multitude is much more, in Borch's words (2013: 288), a "revolutionary subject". The multitude is the answer according to Hardt and Negri to resist the predominant order. Empire is believed to be a decentered and deterritorializing apparatus of rule (Hardt and Negri, 2000: xii) based on a capitalist that is the product of the collapse of the Soviet communism. The multitude is the immanent strategy that acts as a counter-power within and against Empire (Hardt and Negri, 2000: 61), a postmodern resistance using the logics of the Empire (its decentralized network) to turn down its functioning. So, in a postmodern world, the conditions of doing resistance change. While crowd protests, social movements and general strikes should have been effective, today it is a new agent, the multitude, that take place the crowd (Borch, 2013: 291).

Despite Hardt and Negri do say it, we would add that, after the discussion taken by Empire and Multitude, it is the multitude that is prone to displace the public as the most apt collective agent to adapt to postmodern societies. The multitude is, then, the revolutionary subject who turns explicit the obsolescence of traditional political institutions. It is as if the multitude is for the postmodern politics what the public was to modern societies. Hardt and Negri (2004) are thus claiming a new political lexicon, while Virno (2004) argues the specific grammar of the multitude. Just like a new democratic understanding has arisen since the rise of the public, the multitude is actively claiming a new modus operandi of politics. And just like the public is an eminent communicational concept, the multitude demands communication in order to be apprehended. The most vibrant example of this lies in the role networked communications (internet, social networks, Web 2.0) play today on the visible materialization of the multitude through crowds, protests and political humor and irony.

If an emancipatory role can be attributed to the public, the multitude is described to take that concept to another level, that of comprehensiveness: immanent emancipation. A politics to everyone. Or better, a society by everyone, the many, the anonymous multitude. Hardt and Negri see in the multitude the spinozian potential, an indwelling capacity to act (Ruddick, 2010: $25)$, a constitutive power that has become a political agent.

\section{Conclusion}

In this paper we have analyzed the interplay between two central ideas of contemporary social theory: the public and the multitude. We have taken a path that exams these collective agents in close proximity departing from its similarities (inclusiveness, the common) through some different approaches to collective agency (social body, plural singularities) until reach again a kind of similarity (emancipation).

We have claimed that the public and the multitude, as it has been theorized, put high the idea of common. But in the first case the common signifies mainly a symbolic departure to a critical subjectivity. With the multitude, this subjectivity is more radical and even more committed to emancipation and revolution. Hardt and Negri (2000) define the multitude as the ultimate form 
of resistance to power. They see in the constitutive power (potential) of the multitude as a counter power. Just like the multitude, the public operates many times as counter-power. The public, like the multitude, is a form of collective agency that battles installed powers.

The public and the multitude make publicity its premise and reveal a communicational foundation of publicity. Demands need to be shared, emotionalized, enacted, performed and sanctioned publicly. Media play a crucial role on this exemplifying the symbolical and technologically network of individuals.

The aspect that most clearly separates the public and the multitude is the dialogue that establish with the category of universality. While singularities are individualized in the own constitution of the public (the public sphere is defined as private people gathered in public), in the multitude plural singularities, after Hardt and Negri (2004) do not aspire to universality. The general common is the basic premise of their association, not an elective affinity, a particular interest or the coincidence of reading the same newspaper (public).

If we would want to synthesize, one could say that the public is undoubtedly a modern conception and the Hardt and Negri's multitude is a postmodern approach to collective subjects. This does not mean the public is not fundamental to contemporary times. Not at all. It is precisely because the public and the multitude are central notions in today's societies that a comparative analysis is required. Today's protests, social movements, media audiences or crowds display a panoply of forms that put in question the traditional idea of the public. The concept of multitude has gained traction and many authors from both communication studies and political science are paying attention to it. We may interpret this tendency as the confirmation of the intermingling of both concepts in today's many forms of public intervention. A central assertion of this paper is that we need to consider the public and the multitude as possibly being interdependent. At some angles, the multitude seems to be type of pre-public: an immanent power that can evolve to be a potential critical reasoning force. Like the multitude, the public is sometimes associated with a disseminated and distributed authority. The multitude could eventually be considered a pre-public because, as we have seen, there many coincidental aspects. We discard the whole idea of a proto-public since the constitutive power (potencia, not potestas) of the multitude does not consubstantiate in the formation of a critical and rational subject. The multitude is not an incomplete form of the public. From multitudes, publics could eventually stem. In this sense, the multitude may lead to the formation of the public meaning that is those specific cases the multitude acts like zero-degree of the public, a pre-public.

However, compared to the public, the multitude lacks the logocratic dimension the public has. It lacks speech, deliberation or opinion. It lacks reason and linguistic discourse. But, on other hand, maybe what Hardt and Negri (2004) see as a power (potentia) on the idea of multitude is that very absence. Maybe because the multitude is less than a public that it is something more than it. The advantage of dealing with the multitude is to conceive a collective agency so dispersed and heterogenic that resistance is more effective. This seems to be what the theory of the public has difficulty to accept.

The analysis of the complexity of postmodern societies must lie on interdisciplinary readings and hybrid approaches. As such concept as almost-public exemplifies, traditional theory of the public may not be sufficient. Maybe the idea of public will benefit if related to the multitude. We have referred to this connection as an (un)expected relation. We have been inspired in the latin etymology of expectare: to look thoroughly. The relation between the public and the multitude could not be anticipated, could not be forecasted twenty years ago. So it may be unexpected. Yet, social analysis must now presume the linking between them. Especially when the public, the multitude and crowds depend on networked media to make them visible. In this case, the relation among the public and the multitude is not just awaited. It is, above all, a relation we hope for. It is a long expected relation. 


\section{Bibliographical References}

Arendt, Hannah (1958), The Human Condition, Chicago, Illinois: University of Chicago Press, 2001.

Aristotle (1999), Politics, Kitchener: Batoche Books.

Armstrong, Aurela (2009), "Natural and Unnatural Communities: Spinoza beyond Hobbes", British Journal for the History of Philosophy, vol.17, no2, pp.279-305.

Balibar Etienne (1985), "Spinoza, the Anti-Orwell: The Fear of the Masses", in Masses, Classes,

Borch, Christian (2013), The Politics of Crowds - an alternative history of sociology, Cambridge: Cambridge University Press.

Bratich, Jack Z (2005), "Amassing the Multitude: revisiting early audience studies", Communication Theory, no15, vol.3, pp.242-265.

Cammack, Daniela (2013), "Aristotle on the Virtue of the Multitude", Political Theory, vol.41, no2, pp.175-202.

Cannetti, Elias (1960), Crowds and Power, New York: Farrar, Straus and Giroux, 1984.

Dayan, Daniel (2001), "The Peculiar Public of Television", Media, Culture\&Society, vol.23, no6, pp.743-765.

Demarest, Boris (2011), "The Ideal (of) Democracy: multitude and multiplicity in Spinoza's Political Ontology", Rethinking Europe Book Series, vol.1, pp.64-73

Gabriel Tarde (1901), L'Opinion et la Foule, Paris : Les Presses universitaires de France, 1989.

Gustave Le Bon (1895), The Crowd: A Study of the Popular Mind, New York: Mineola, 2002.

Habermas, Jürgen (1962), The Structural Transformation of the Public Sphere: An Inquiry into a category of Bourgeois Society, Massachusetts: MIT Press, 1991.

Hardt, Michael, and Negri Antonio (2004), Multitude, New York, The Penguin Press.

Hardt, Michael, and Negri, Antonio (2000), Empire, Harvard : Harvard University Press.

Hegel, Georg WF (1821), Philosophy of Right, Kitchener: Batoche Books, 2001.

Hobbes, Thomas (1647), On the Citizen. Cambridge: Cambridge University Press, 2003.

Ideas: Studies on Politics and Philosophy Before and After Marx, New York and London: Routledge, 1985.

Jakonen, Mikko (2011), "The Concept of Multitude and Thomas Hobbe's Theory of International Relations/World Politics", SIES-WP, vol.2011, no7.

Lippman, Walter (1925), The Phantom Public, New York: Transaction Publishers, 1993.

Maquiavelli, Niccolo (1517), Discourses on the First Decade of Titus Livius, The Electronic Classics Series, 2007.

Marcos, Roberto Gelado (2009), "Hardt and Negri's Multitude: illusion or reality?", Revista Facultad de Derecho y Ciencias Politicas, vol.39, no110, pp.15-31.

Mazarella, William (2010), "The Myth of the Multitude, or who's afraid of the crowd?", Critical Inquiry, no36, pp. 697-727. 
Millan, Stefania (2013), Social Movements and Their Technologies: Wiring Social Change, London: Palgrave MacMillan.

Ruddick, Susan (2010), "The Politics of Affect - Spinoza in the work of Negri and Deleuze", Theory, Culture \& Society, vol.27, no4, pp.21-45.

Sennett, Richard (1974), The Fall of Public Man, New York and London, Norton \& Company, 1992.

Spinoza (1677), Political Treatise, Hackett Publishing Company, 2010

Surowiecki, James (2004), The Wisdom of Crowds: Why the Many Are Smarter Than the Few and How Collective Wisdom Shapes Business, Economies, Societies and Nations Little Brown: Anchor.

Virno, Paolo (2004), A Grammar of the Multitude, Los Angeles, Semiotexte.

Waldron, Jeremy (1995), "The Wisdom of the Multitude: some reflection on Book 3, chapter 11 of Aristotle's Politics", Political Theory, vol.23, no4, pp.563-584.

Walter Lippman (1922), Public Opinion, Dover Publications, 2012. 